\title{
Suitability of Flood Plain Deposits for the Production of Burnt Bricks in Parts of Benue State, Central Nigeria
}

\author{
A. C. Tse \\ Department of Geology, University of Port Harcourt, Nigeria
}

\begin{abstract}
In Benue State, Central Nigeria, flood plain soil deposits along the banks of major rivers and seasonal streams are used as raw materials in the local manufacture of burnt bricks for the construction of houses. This work evaluates the compositional characteristics of the soils and engineering properties of derived bricks to assess their suitability and as alternatives to sandcrete as load bearing materials in the construction of houses. The soils are composed of varying proportions of sand, silt and clay. While the sand fraction is mainly fine to medium grained, the clays are of low plasticity. The chemistry of the soils show that the order of abundance of the major oxides is $\mathrm{CaO}>\mathrm{Fe}_{2} \mathrm{O}_{3}>\mathrm{MgO}>\mathrm{TiO}_{2}>\mathrm{PbO}>\mathrm{MnO}>\mathrm{Al}_{2} \mathrm{O}_{3}>$ $\mathrm{P}_{2} \mathrm{O}_{5}>\mathrm{K}_{2} \mathrm{O}>\mathrm{Na}_{2} \mathrm{O}>\mathrm{SiO}_{2}>\mathrm{AgO}$. Test cube bricks produced under standard compaction methods gave cold water absorption of 3-4\%, ignition loss of $31-36 \%$ and compressive strength of between 38 and $111 \mathrm{~N} / \mathrm{mm}^{2}$. These parameters satisfy the requirements specified by relevant Nigerian Standards for burnt bricks. The locally made bricks by the natives on examination exhibited cracks and shades of different colours due to thermal stress suggesting that low compactive efforts were applied during kneading of the soil into the molds and also that the bricks were not adequately fired. This quality deficiency is due to non -standardization of the hand production process. If properly harnessed, these widely available raw materials and their cheap products will readily substitute cement bricks for most housing and other structural work.
\end{abstract}

Keywords flood plains, burnt bricks, major oxides, sandcrete, compressive strength

\section{Introduction}

In many parts of rural communities in Nigeria, traditional housing units are made of mud bricks walls due to inability of individuals to afford sandcrete blocks. A significant decline in the capacity utilization of all cement manufacturing plants in Nigeria since the 1990s, has raised the already exorbitant cost of this fundamental building material above the reach of the average Nigerian. This has given rise to the emergence of a strong local burnt bricks industry in many parts of Benue State, Central Nigeria. The bricks are made in various sizes using a local adaptation of the standard process controlled burnt brick technology. The raw materials comprise solely soil deposits found along the flood plains of major rivers and seasonal streams. Traditionally, these plains are used by the natives in the cultivation of paddy rice during the rainy season. In the dry season however, the river/stream banks are used to produce bricks by small scale moulding and burning. The process involves excavating the earth material with a hoe followed by manual mixing with water into a plastic paste. The mix is then kneaded and compacted in wooden moulds, extruded and sun-dried and then fired with

* Corresponding author:

akaha.tse@uniport.edu.ng (A.C. Tse)

Published online at http://journal.sapub.org/geo

Copyright (C) 2012 Scientific \& Academic Publishing. All Rights Reserved wood fuel. The firing technique requires the careful arrangement of the sun-dried bricks in tabular or pyramid shaped heaps provided with several interconnecting tunnels to allow for circulation of air and heat. The tunnels are then stuffed with dry wood which is the source of fuel and fired until the colour of the bricks turns from natural gray into red. However, the locally made products sometimes show shades of gray, red and ash colours when they are insufficiently fired. Another limitation is the non standardization of both the soil-water mix and the compactive effort, resulting in their high porosity. Although there are abundant raw materials, but the problem is to meet basic standards for proper performance e.g. compressive strength minima of $3.5 \mathrm{MN} / \mathrm{m}^{2}$ and water absorption of not more than $20 \%$ are rarely met (Ibanga and Ahmed, 2007).

Burnt bricks locally produced in this fashion have gained widespread acceptance even among the top strata of the society as alternative to cement blocks in the construction of residential and industrial houses. Houses built with these bricks are reported to be cooler than those built with cement blocks since burnt bricks are poorer conductors of heat than cement bricks, giving rise to good insulation properties that contribute to greater thermal comfort. In addition to being fire resistant because of the high temperatures of firing, they also have higher aesthetics than unpainted cement blocks. By Cost savings achieved in a standard family bungalow (3-4 bedroom) may be as much as $30 \%$. 
The widespread use of the locally produced burnt bricks and its increasing popularity in many rural and urban communities especially in the Tiv speaking areas of the State has made it imperative to evaluate the compositional and geotechnical properties of the soils and the finished burnt bricks. This is to determine their suitability for use as construction materials for building houses and other similar engineering structures. Four sites in Benue State were selected for this study on the basis of geologic setting, and scale of activity. These are Makurdi, the capital city of Benue state, KatsinaAla in Katsina-Ala Local Government Area, Nyaro-Tsambe in Vandeikya Local Government Area and Naka in Gwer West Local Government Area. The only government owned modern burnt brick factory located in Otukpo town, situated about $100 \mathrm{~km}$ south of Makurdi, which started production in the late 1970s and was thriving commercially, suddenly collapsed in the 1990s.

Mesida (1978) examined properties of raw materials and burnt bricks produced from Nigerian soils such as the utilization of lateritic clays at Ala River, Akure and Okeigbo near Ondo, Nigeria. He obtained high crushing strength values for bricks made from the different varieties of clay and found them to be suitable for bricks and ceramics industries in view of their good quality. Durotoye et al (1988) and Ogunsawo (1989) also obtained similar results for the clay deposits in parts of south western Nigeria.

\section{Geography of Study Area and Sampling Sites}

The study areas are located in Benue State in the Middle Belt area of Nigeria (politically referred to as North Central Nigeria) which lies between latitudes $6^{\circ}$ and $8^{\circ} \mathrm{N}$ and longitudes $7^{\circ}$ and $10^{\circ} \mathrm{E}$, covering an area of about $50460 \mathrm{~km}^{2}$ (Fig 1). Soil samples were obtained from the flood plains of River Benue at Makurdi, and River Katsina Ala at Katsina Ala, while the major seasonal streams including the Gwer at Naka, and Nyaro in Tsambe, provided the sites for this study. The banks of these rivers are often submerged during the rainy season, producing the flood plain deposits made up of fine to medium grained sand, silt and clay, in varying proportions. However the waters dry up in the dry season, making available 15 to $30 \mathrm{~m}$ wide stretch of the river banks which yield the raw materials and provide the sites for this thriving local industry. The climate is tropical with an annual rainfall of between 1300 and $3000 \mathrm{~mm}$. The vegetation of the studied area consists of tall grasses, deciduous trees and savannas.

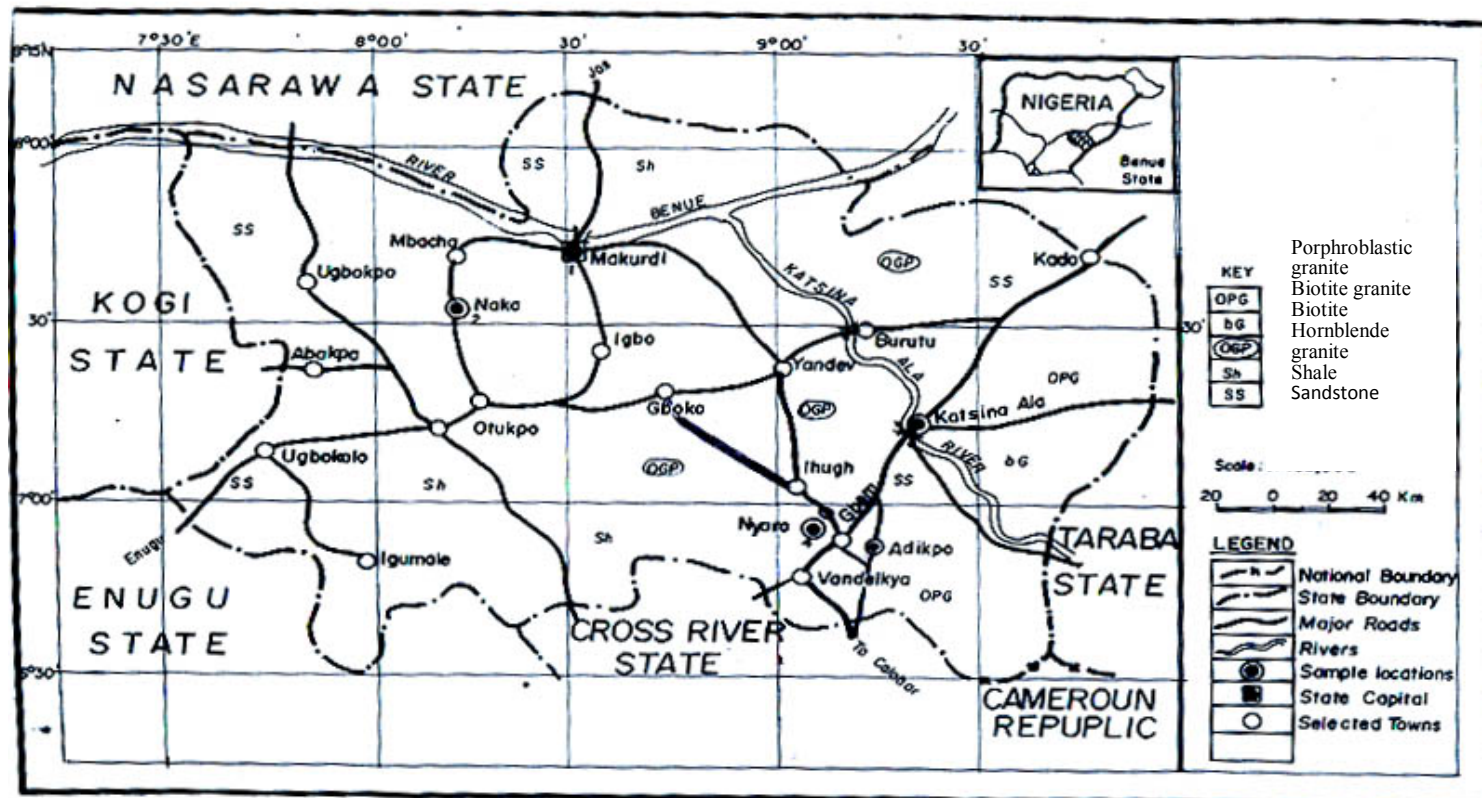

Figure 1. Map of Benue State showing rock distribution and sampling locations

Table 1. Stratigraphic sucession in the Midle Benue Trough, Nigeria

\begin{tabular}{ll}
\hline AGE & FORMATION \\
\hline Tertiary-Quaternary & Alluvium Volcanics \\
Maastrichtian & Lafia \\
Campanian & \\
Santonian & Awgu Shale \\
Coniacian & Ezeaku Group (Including Makurdi sandstone) \\
Turonian & Keana, Awe \\
Cenomanian & Asu River Group (include, Gboko and Arufu Limestone) \\
Albian & Basement Complex \\
Pre- Albian & \\
\hline
\end{tabular}




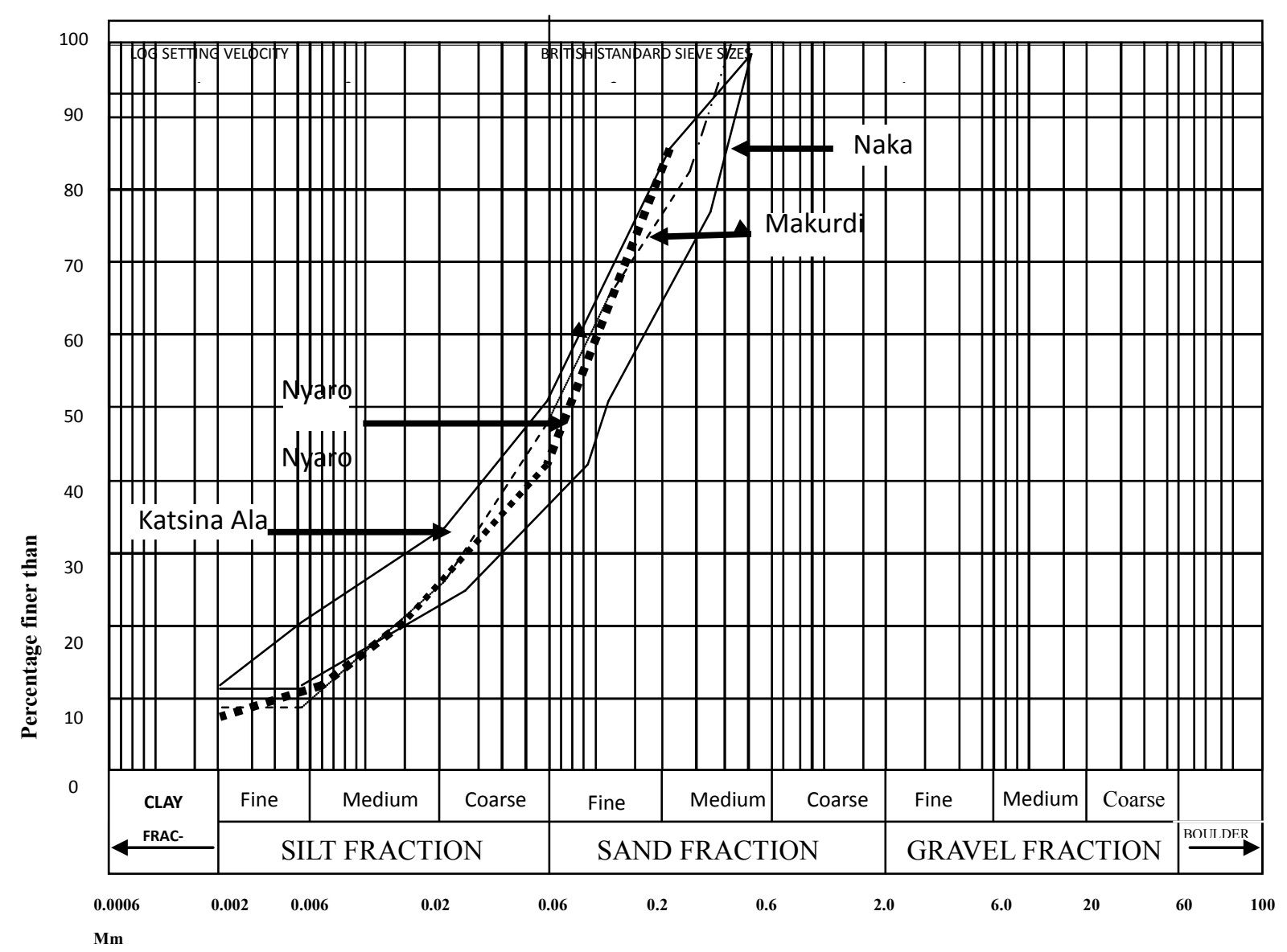

Figure 2. Typical particle size distribution curves of the soils

Table 2. Atterberg Limits and specific gravity of the soils

\begin{tabular}{|c|c|c|c|c|c|c|}
\hline Location & Sample & Liquid Limit (\%) & Plasticity Limit $\%$ & Plasticity Index \% & \% Linear Shrinkage & Specific gravity \\
\hline \multirow{2}{*}{ Makurdi 1} & 1 & 38.4 & 20.9 & 17.5 & 10.0 & \multirow{2}{*}{2.76} \\
\hline & 2 & 36.0 & 19.5 & 16.5 & 10.7 & \\
\hline \multirow{2}{*}{ Makurdi 2} & 1 & 33.5 & 11.8 & 21.7 & 14.3 & \multirow{2}{*}{2.83} \\
\hline & 2 & 38.8 & 24.1 & 14.7 & 11.0 & \\
\hline Makurdi 3 & 1 & 34.6 & 12.2 & 22.4 & 11.0 & 2.79 \\
\hline \multirow{2}{*}{ Katsina Ala } & 1 & 29.8 & 22.2 & 7.6 & 12.1 & \multirow{2}{*}{2.67} \\
\hline & 2 & 33.4 & 13.5 & 19.9 & 6.4 & \\
\hline \multirow{2}{*}{ Nyaro-Tsambe } & 1 & 32.3 & 13.1 & 19.2 & 3.6 & \multirow{2}{*}{2.62} \\
\hline & 2 & 33.4 & 20.1 & 13.3 & 5.0 & \\
\hline \multirow{2}{*}{ Naka } & 1 & 32.5 & 22.5 & 10.0 & 14.3 & \multirow{2}{*}{2.64} \\
\hline & 2 & 32.5 & 22.2 & 10.3 & 15.0 & \\
\hline
\end{tabular}

Table 3. Water absorption and ignition loss results of the test bricks

\begin{tabular}{|c|c|c|c|c|c|}
\hline Location & Sample & Colour before firing & Colour after firing & Water absorption(\%) & Ignition loss (\%) \\
\hline \multirow{2}{*}{ Makurdi 1 } & 1 & Dark brown & Brick red & 4.1 & 35.6 \\
\cline { 2 - 6 } & 2 & Dark brown & Brick red & 4.3 & 33.2 \\
\hline \multirow{2}{*}{2} & 1 & Light grey & Brick red & 4.3 & 34.9 \\
\cline { 2 - 6 } & 2 & Light grey & Brick red & 4.8 & 32.6 \\
\cline { 2 - 6 } & 2 & Dark brown & Brick red & 5.1 & 30.6 \\
\hline \multirow{2}{*}{ Katsina Ala } & 1 & Dark brown & Brick red & 4.4 & 35.8 \\
\cline { 2 - 6 } & 2 & Dark brown & Brick red & 3.9 & 34.2 \\
\hline \multirow{2}{*}{ Nyaro-Tsambe } & 1 & Dark brown & Brick red & 3.2 & 33.8 \\
\cline { 2 - 6 } & 2 & Dark brown & Brick red & 5.4 & 36.5 \\
\hline \multirow{2}{*}{ Naka } & 1 & Dark brown & Brick red & 4.5 & 31.7 \\
\cline { 2 - 6 } & 2 & Dark brown & Brick red & 4.1 & 35.0 \\
\hline
\end{tabular}


Table 4. Bulk Density and Crushing Strength of the test bricks

\begin{tabular}{|c|c|c|c|c|c|}
\hline Location & Dimension of brick (mm) & Weight (g) & $\begin{array}{c}\text { Bulk density } \\
\left(\mathrm{g} / \mathrm{cm}^{3}\right)\end{array}$ & $\begin{array}{l}\text { Crushing Strength } \\
\left(\mathrm{N} / \mathrm{mm}^{2}\right)\end{array}$ & $\begin{array}{l}\text { Average Crushing } \\
\text { Strength }\left(\mathrm{N} / \mathrm{mm}^{2}\right)\end{array}$ \\
\hline Makurdi 1 & $60 \times 60 \times 60$ & 282 & 1.31 & 64.90 & \multirow[b]{3}{*}{98.36} \\
\hline Makurdi 2 & $60 \times 60 \times 60$ & 299 & 1.38 & 111.00 & \\
\hline Makurdi 3 & $60 \times 60 \times 60$ & 318 & 1.47 & 120.00 & \\
\hline Katsina Ala 1 & $60 \times 60 \times 60$ & 337 & 1.56 & 47.40 & \multirow[b]{2}{*}{46.55} \\
\hline Katsina Ala 2 & $60 \times 60 \times 60$ & 368 & 1.70 & 45.70 & \\
\hline Nyaro 1 & $60 \times 60 \times 60$ & 366 & 1.69 & 39.17 & \multirow[b]{2}{*}{41.30} \\
\hline Nyaro 2 & $60 \times 60 \times 60$ & 372 & 1.72 & 43.43 & \\
\hline Naka 1 & $60 \times 60 \times 60$ & 278 & 1.29 & 37.96 & \multirow[b]{2}{*}{42.03} \\
\hline Naka 2 & $60 \times 60 \times 60$ & 313 & 1.45 & 46.10 & \\
\hline
\end{tabular}

Table 5. British Building Research Station Engineering Classification of Bricks based on strength (Fisher, 1972)

\begin{tabular}{|c|c|c|}
\hline Designation & Class & Average Compressive Strength not less than $\left(\mathrm{N} / \mathrm{mm}^{2}\right)$ \\
\hline Engineering brick & A & 68.95 \\
\hline Engineering brick & B & 48.26 \\
\hline Load bearing brick & 15 & 103.42 \\
\hline Load bearing brick & 10 & 68.95 \\
\hline Load bearing brick & 7 & 48.26 \\
\hline Load bearing brick & 5 & 34.47 \\
\hline Load bearing brick & 4 & 27.58 \\
\hline Load bearing brick & 3 & 20.68 \\
\hline Load bearing brick & 2 & 13.79 \\
\hline Load bearing brick & 1 & 6.89 \\
\hline
\end{tabular}

Table 6. Major oxides composition of the soils (\%)

\begin{tabular}{|c|l|l|l|c|c|c|c|c|c|c|c|c|}
\hline Sample Location & $\mathrm{CaO}$ & $\mathrm{MgO}$ & $\mathrm{K}_{2} \mathrm{O}$ & $\mathrm{Na}_{2} \mathrm{O}$ & $\mathrm{Al}_{2} \mathrm{O}_{3}$ & $\mathrm{SiO}_{2}$ & $\mathrm{M}_{\mathrm{n}} \mathrm{O}$ & $\mathrm{A}_{\mathrm{g}} \mathrm{O}$ & $\mathrm{P}_{\mathrm{b}} \mathrm{O}$ & $\mathrm{Fe}_{2} \mathrm{O}_{3}$ & $\mathrm{TiO}_{2}$ & $\mathrm{P}_{2} \mathrm{O}_{5}$ \\
\hline Makurdi 1 & 27.58 & 14.73 & 1.30 & 0.62 & 5.38 & 0.39 & 5.83 & 0.03 & 7.08 & 20.33 & 13.37 & 3.34 \\
\hline Makurdi 2 & 20.99 & 12.30 & 1.02 & 0.51 & 3.31 & 25.7 & 4.67 & 0.03 & 5.09 & 13.61 & 10.18 & 2.59 \\
\hline Makurdi 3 & 27.64 & 15.08 & 1.14 & 0.60 & 4.99 & 0.04 & 7.03 & 0.03 & 7.03 & 20.43 & 13.10 & 2.88 \\
\hline Katsina Ala & 27.71 & 16.27 & 1.39 & 0.64 & 5.29 & 0,28 & 7.15 & 0.35 & 6.62 & 18.50 & 13.07 & 2.73 \\
\hline Nyaro-Tsambe & 27.90 & 15.22 & 1.12 & 0.62 & 4.41 & 0.34 & 6.03 & 0.04 & 7.58 & 20.82 & 13.24 & 2.67 \\
\hline Naka & 28.40 & 15.23 & 1.30 & 0.65 & 4.01 & 0.24 & 6.20 & 0.04 & 6.79 & 20.3 & 13.58 & 3.25 \\
\hline
\end{tabular}

\section{Geological Setting}

Benue State lies within the Middle Benue Trough which is a 80 to $150 \mathrm{~m}$ wide and $800 \mathrm{~km}$ long, NE, SW trending structure considered to have originated as an aulacogen. (Hoque and Nwajide, 1984.). The geology of the trough and models of its origin have been proposed and described by various authors. The triple junction rift model (RRR) explains the trough originated as the failed third arm of a rift during the separation of South America from Africa during the Cretaceous. The two arms of the RRR rift system are thought to have formed the Atlantic Ocean, and the third, the failed arm, is represented by the Benue Trough (Reyment, 1965; Grant, 1965; Burke et al 1970; and Wright, 1981). However, others including and Benkhelil (1982) attributed the origin of the trough to the onshore extension of equatorial oceanic fracture zones along the NW and SE margins of the trough. It is usually divided into upper, middle and lower sections each with varying stratigraphic successions. The crystalline basement which outcrops in some places in the Middle Benue Trough, is characterized by many major and minor intrusive ( Cratchley and Jones, 1965; Mccurry, 1976). The geology of Benue State is summarized in Fig.1. Locally, Benue state is underlain by both igneous and sedimentary rocks (Nwofor et al) The igneous rocks make up 25\% of the rock cover and are found in eastern parts of the state. They include basement intrusives and extrusives among which are gabbro, dolerites, basalts, diorite and rhyolites. They are Precambrian to Jurassic in age. The other parts of the state are underlain by thick Cretaceous sediments of various formations, including rocks of the Asu River Group and the Ezeaku Formation. Recent alluvial deposits are found along the valleys of the rivers and other low-lying areas. These consist of gravels, sand, silts and clays. Locally, Naka area is underlain by Albian shales of the Asu River Group. The section of the River Benue in this study consists of Recent alluvial flood plains deposits that overlie the Turonian Makurdi Sandstones. In Katsina Ala area, igneous extrusives consisting essentially of biotite hornblende granite locally outcrop within the sedimentary deposits. Nyaro-Tsambe, is underlain by the sedimentary fill of the Asu River Group.

\section{Methodology}

Sampling was undertaken when the sites were dry and accessible. About $5 \mathrm{~kg}$ of disturbed soil samples were obtained at depths of 15 to $30 \mathrm{~cm}$ along the face of the pits created during excavation of the soils used for the manufacture of bricks by the natives. Root remains and other vegetal materials were removed by sieving through ASTM sieve number $40(0.425 \mathrm{~mm}$ mesh diameter). Particle size distribution, Atterberg limits and linear shrinkage were determined for the soil samples according to the standard 
procedures specified in BS 1377 of 1990. Geochemical analysis to determine the composition of the soil in terms of major oxides was performed in the Soil Science Laboratory of the University of Agriculture, Makurdi by using titration methods as described by Jackson (1970) and by use of a spectrophotometric 20 colorimeter.

The soils used were prepared for the various tests by air drying, mixing and quartering. After the soil was mixed thoroughly with water to a uniform consistency, test cube bricks were made by kneading and compacting these soil in wooden moulds of dimensions $60 \times 60 \times 60 \mathrm{~mm}$. Initially the wet bricks were left in the mould for about six hours to allow for setting. They were then air dried for 48 hours after which they were oven dried at $100^{\circ} \mathrm{C}$ for 24 hours. The oven dried bricks were subsequently placed in the furnace at $1000^{\circ} \mathrm{C}$ for another 24 hours. The gradual drying process was to forestall thermal stress such as cracking due to sudden high temperature drying. The colour changes and the extent of cracking, if any, were observed. These fired bricks were then tested for 24 hour cold water absorption, ignition loss and crushing strength. These are useful indices of durability (Mesida, 1978).

\section{Results and Discussion}

Particle size analysis of the grey to brown coloured soils shows that they are composed of sand (43 - 60\%), silt (25 $40 \%)$ and clay $(8-12 \%)$. The sand is mainly medium to fine grained (Fig 2). A summary of the physical properties and consistency limit results is shown in Table 2 . The low range of the plasticity index of the soils $(10-27 \%)$ with an average of $19 \%$ is consequent of the particle size distribution which indicates less than $15 \%$ of clay which is of low plasticity (CL). The presence of sand, silt and clay sizes is important to achieve a high state of compaction and the desired densification. Similar results were obtained by Mesida (1978) for brick soils developed over basement rocks in South Western Nigeria. Linear shrinkage varies from 3.6 to $15 \%$, and the values fall within the range of $4-25 \%$ specified by Fromme (1994). The results of these index property tests imply that low volume changes will be associated with bricks manufactured using these soils. The colour changes, ignition loss and water adsorption properties of the test cube bricks are shown in Table 3. The bricks, when fired gradually to temperatures of $1000^{\circ} \mathrm{C}$, showed no cracks, but changed colour to brick red from the natural gray-brown hue. The red colour is indicative of the presence of iron. However some of the locally hand-made bricks by (the natives) obtained at the study sites showed cracks and vesicles, and patches of gray-brown colours. This may indicate non-standardized mixing regimen of the soils and inadequate firing of the bricks, suggesting that the local production process is faulty. Okunade (2008), explained that the transformation of raw clay bricks into rigid bricks when fired occurs by a complex set of physical and chemical changes. When clay is fired, the contained water is expelled and silicate glass forms by a reaction between the three natural constituents of clay brick; the clay mineral such as kaolinite; a flux such as sodic or potassic feldspar which forms the glass; and a filler such as quartz which reduces shrinkage. The water absorption of the fired test cubes ranges from $3-4 \%$, which is about half of the maximum $8 \%$ allowed for bricks (Brick, 2000), implying that the bricks will be stable and durable even in wet conditions. The loss on ignition of the bricks range from 3.17 to $3.65 \%$. This indicates that volatiles, mainly organic compounds, escaped during firing. Thus adequate and prolonged firing is necessary. The crushing strength of the fired bricks (Table 4) range from 38 to $111 \mathrm{~N} / \mathrm{mm}^{2}$.

The Standards Organization of Nigeria stipulates that the dry strength of bricks for building should be a minimum of $2.5 \mathrm{~N} / \mathrm{mm}^{2}$ (NIS: 74, 1976). Also, the British Standards Institute (BS 368, 1976) specifies $2.75 \mathrm{~N} / \mathrm{mm}^{2}$ and 1.38 $\mathrm{N} / \mathrm{mm}^{2}$ respectively as minimum values of crushing strength for bricks to be used in 2-storey buildings and non-load bearing walls. Thus, according to the British Building Research Station Classification of bricks based on strength (Fisher, 1992) (Table 5), the bricks from Makurdi with an average crushing strength of $98.63 \mathrm{~N} / \mathrm{mm}^{2}$ may be used for all designations except Load bearing brick class 15, while those from Katsina Ala, Naka and Nyaro -Tsambe with average crushing strength values of $46.55 \mathrm{~N} / \mathrm{mm}^{2}, 42.03$ $\mathrm{N} / \mathrm{mm}^{2}$ and $41.30 \mathrm{~N} / \mathrm{mm}^{2}$ respectively are designated as load bearing bricks class 1 to 5 . The trend of the average crushing strength of the bricks is Makurdi > Katsina Ala > Naka > Nyaro-Tsambe. Hababou (1983) reports that burnt bricks obtained by small scale moulding and burning are of excellent quality and compressive strength of the order of $250 \mathrm{~kg} / \mathrm{cm}$ can be achieved.

The chemistry of the soils show that oxides of calcium, iron and magnesium dominate the soils. The order of abundance of the major oxides (Table 6) is $\mathrm{CaO}>\mathrm{Fe}_{2} \mathrm{O}_{3}>\mathrm{MgO}>$ $\mathrm{TiO}_{2}>\mathrm{PbO}>\mathrm{MnO}>\mathrm{Al}_{2} \mathrm{O}_{3}>\mathrm{P}_{2} \mathrm{O}_{5}>\mathrm{K}_{2} \mathrm{O}>\mathrm{Na}_{2} \mathrm{O}>\mathrm{SiO}_{2}>$ $\mathrm{Ag}_{2} \mathrm{O}$. The Average results for two samples at each locations.

Similarities in the geochemical results of the soils suggests that they may have been derived from similar geological processes. The high proportion and abundance of calcium and iron oxides may be important factors for the high strength of the sample bricks, since they are chemical binders of soil particles. The enrichment of the soils in oxides of $\mathrm{Ca}$, $\mathrm{Fe}, \mathrm{Mg}$. and $\mathrm{Ti}$ with a corresponding depletion in $\mathrm{SiO}_{2}$ and $\mathrm{Al}_{2} \mathrm{O}_{3}$ indicates that the soils are product of chemical weathering of laterites. Fluvial processes from the rivers and streams may have transported them from source and deposited them at their present sites following the overflow of their banks during high precipitations that resulted in flooding.

\section{Summary and Conclusions}

The properties of soils investigated in this study indicate that the clayey soils from the flood plains of some rivers in the Benue area are suitable for the production of burnt bricks. 
At present, massive use is made of the bricks both in rural and urban areas for housing in most parts of Benue State. The compressive strength of the bricks surpass the minimum strength requirement of $2.5 \mathrm{~N} / \mathrm{mm}^{2}$ specified by Nigerian Standards (N1S.74: 1976) for burnt bricks. The study also established that poor production procedures are mainly responsible for lower quality of most of the locally produced bricks by the natives. Standardized production procedures will achieve exceptionally high results. It is recommended that government should partner with local producers to develop this potentially successful industry whose products are popular. Development of this community based industry will assist government to cheap and locally sourced materials in the construction industry, especially for housing projects. This will stimulate the local economy and help to achieve the first millennium development goal

\section{ACKNOWLEDGEMENTS}

The authors acknowledge the assistance of John Nwankwo and Joseph Awusa who helped during the field-sampling phase of the work. Also, the assistance of the Laboratory staff in the Departments of Civil Engineering and Soil Science, University of Agriculture, Makurdi, Nigeria, is gratefully acknowledged, as well as the anonymous reviewers who upgraded the quality of this paper.

\section{REFERENCES}

[1] Benkhelil, J. 1993. The origin and evolution of the Cretaceous Benue Trough, Nigeria Journal African Earth Sciences. 8, Pp 251-282.

[2] Benkhelil, J. 1982a.Benue Troughand Benue Chain.Geol. Mag. V. 119,p.155-168

[3] Brick, S. 2000. Clay Brick Specification. http://www. shawberick.ca/Res section

[4] British Standards Institute, 1976. British Standards for Bricks. BS 368. 56p

[5] British Standards Institute, 1990. British Standard methods of tests for soils for Civil Engineering purposes. BS1377: Part 2, $61 \mathrm{p}$

[6] Burke, K.C. Dessauvagie, T.F.J. and Whiteman,A.J. 1970. Geological history of the Benue valley and adjacent areas. In African Geology (ed. T.F.J. Dessauvagie and A.J.Whitemsn.. Pp. 187-205. Ibadan (Nigeria): geol Dept. Ibadan Univ.

[7] Cratchley, C.P; and Jones, G.P. 1965. An interpretation of the geology and gravity anomalies of the Benue Valley. Nigeria Overseas Geol. Survey. Geophys. Paper I, pp.26

[8] Durotoye, B., Ige, A., and Awojide P.O. 1988. Small scale mining of clay deposit at Ipetumodu,

[9] Near Ile Ife, Oyo State . Journal of Mining and Geology Vol. 24 Nos. $1 \& 2$ PP. 65-69
[10] Emofurieta, W.O., Ogundimu T.O and Imeokparia E. 1994. Mineralogical and Economic appraisal of some clay and shale deposits in South Western and North Eastern Nigeria. JMG Vol. 30 No 2. PP.151-159.

[11] Fisher, R. 1972. Walls: Essence Books on Building Series. Macmillan. London. 137 pp.

[12] Fromme, R. 1994. Basic Notes on Clays and Clay bodies. In: Glaze and Clay Tutorial 2. http://Cator.hsc.edu/ kmd/ cavenman/projects/pottery/basic clay.html.Retrieved 2008.

[13] Grant, N.K. 1965. The geology of parts of Dadiya syncline, northeastern Nigeria. Nigerian J. Min. Geol. v.21, Nos.1 \&2. P.19-26

[14] Hoque,M and Nwajide, C.S. 1984. Tectono-sedimentological evolution of an elongate intracratonic basin ( aulacogen): The case of the Benue Trough of Nigeria. Nigerian J. Min. Geol. V. 2, P.17

[15] Ibanga, E.J. and Ahmed, M. 2007. Influence of particle size and firing temperature on burnt properties of rice/clay mix. The Pacific Journal of Science and Technology. Vol. 8. No. 2.p.267-270.

[16] Jackson, M.L. 1970. Soil Chemical 1976 Analysis. Prentice Hall Inc. New York

[17] Hababou, L, 1983. The use of local materials in the construction of health care facilities. WHO Offset press. Geneva. 119 p.

[18] McCurry, P. 1976. The geology of the Precambrian to Lower Paleozoic rocks of Northern Nigeria.-a review. In Geology of Nigeria.pp.15-39. Edited by Kogbe, C.A.. Elizabethan Pub.Co. Lagos.

[19] Mesida, E.A. 1978. Utilization of some Lateritic Clays for Burnt Bricks. Journal of Mining and Geology. Vol.15 No 2 PP.108-114

[20] Nwafor, G.L; Uduji, E.R and Kwache, J.B. 1997. A compiled report of four giant mineral deposits in Benue State. Geological Survey of Nigeria, Makurdi. 43p

[21] Obaje, N.G., Ligouis, B., and Abaa, S.I. 1994. Petrographic composition and depositional environment of Cretaceous coals and coal measures in the Middle Benue Trough of Nigeria. Int. Journ. Coal Geol, Vol.2 pp.233 - 260

[22] Offodile, M.E. 1976. The Geology of Middle Benue, Nigeria. Publication, Paleontology Institution, University Upsalla.4, pp. L-66.

[23] Ogunsawo, O. 1989. CBR and strength of compacted soils from southwestern Nigeria. QJEG. Vol. 22;No.4. p. 317-328.

[24] Okunade, E.A.2008. Engineering properties of locally manufactured burnt brick pavers for agrarian and rural earth roads. American Journal of Applied Science 5 (10) 1348-1351

[25] Reyment, R.A. 1965. Aspects of the Geology of Nigeria. Ibadan University Press 145 PP.

[26] Nigeria Institute of Standards. 1976. Nigeria Specification for Burnt Bricks. 74: Ude .624.0

[27] Wright, J.B. 1981. Review of the origin and evolution of the Benue Trough in Nigeria. Earth Evolution Sci. v. 1,p. 98-102. 